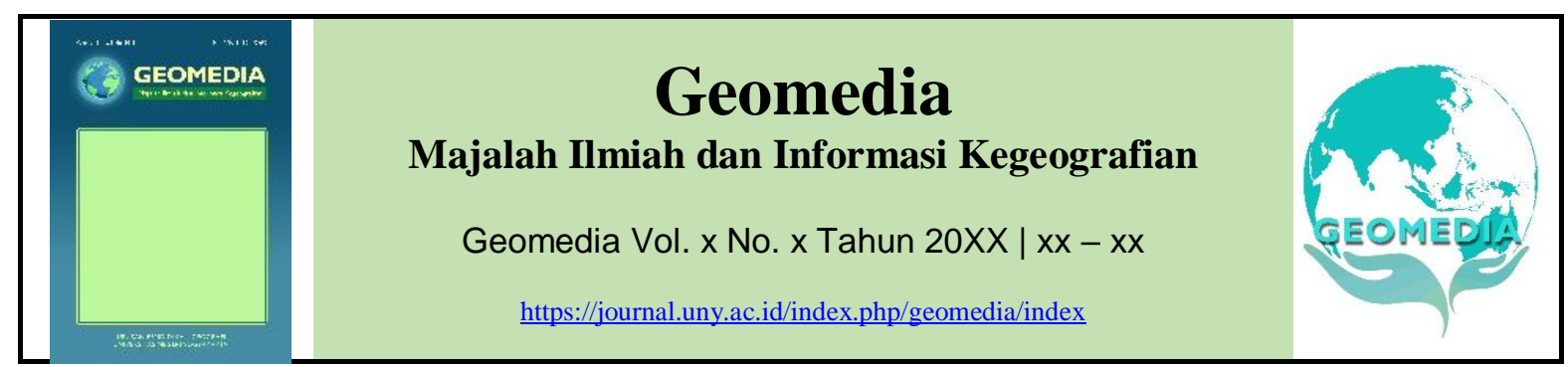

\title{
Hidrogeomorfologi mataair kaki Vulkan Merapi bagian selatan
}

\author{
Sholu Ratih ${ }^{1 *}$, Hervina Nur Awanda ${ }^{2}$, Anton Cesar Saputra ${ }^{3}$, Arif Ashari, 4 \\ Jurusan Pendidikan Geografi, Fakultas IImu Sosial, Universitas Negeri Yogyakarta

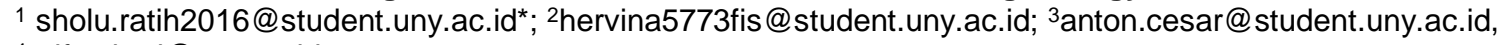 \\ 4arif.ashari@uny.ac.id \\ *korespondensi penulis
}

\begin{tabular}{ll}
\hline Informasi artikel & A B S T R A K \\
\hline Kata kunci: & Keberadaan mataair pada suatu wilayah merupakan potensi sumberdaya \\
mataair & alam yang perlu dimanfaatkan secara optimal. Lereng selatan Vulkan \\
sabuk mataair & Merapi sebagai bagian dari vulkan strato muda memiliki potensi sumber \\
vulkan & mataair. Dalam upaya melakukan pengelolaan mataair informasi \\
Merapi & mengenai distribusi spasial mataair sangat diperlukan. Penelitian ini \\
bentuklahan & dilaksanakan pada lereng selatan Vulkan Merapi dengan tujuan: (1) \\
& menganalisis pola persebaran mataair berdasarkan satuan bentuklahan, \\
& (2) menganalisis pengaruh kondisi morfologi terhadap persebaran \\
& mataair. Metode yang digunakan mencapai tujuan adalah survei \\
& geomorfologis dengan pengambilan sampel secara sistematik. Analisis \\
& data dilakukan secara deskriptif-eksploratif dengan memperhatikan aspek \\
& spasial didukung analisis SiG dengan nearest neighbour analysis. Hasil \\
& penelitian: (1) pada lereng selatan Vulkan Merapi terdapat pemunculan \\
mataair dengan pola mengelompok pada satuan bentuklahan kaki vulkan & dan dataran kaki vulkan. Pola mengelompok ini mengindikasikan sistem \\
sabuk mataair. (2) kondisi geomorfologis berpengaruh terhadap \\
persebaran mataair, terutama faktor bentuklahan, proses geomorfologi, \\
dan litologi. Anomali persebaran mataair pada bagian timur merupakan \\
contoh pengaruh proses geomorfologi berupa vulkanisme aktif yang \\
membatasi keterdapatan mataair.
\end{tabular}

\section{Keywords:}

spring springbelt

volcano

Merapi

landform

\begin{abstract}
A B S T R A C T
The existence of springs in a region is a potential natural resources that need to be utilized optimally. The southern flank of Merapi Volcano as part of a young strato volcano has a potential source of springs. In an effort to conduct springs management information on spatial distribution of springs is necessary. This research was conducted on the southern flank of Vulkan Merapi with the aim: (1) analyzing the spreading pattern of springs based on Indform unit, (2) analyzing the effect of morphological conditions on the distribution of springs. The method employs to achieve the goal is a geomorphological survey with systematic sampling. Data analysis was done descriptively-explorative by considering spatial aspect supported by GIS analysis with nearest neighbor analysis. The results: (1) on the southern flank of Merapi Volcano there are the emergence of the spring with clustered pattern on the unit landform of volcanic foot and volcanic foot plains. This clustered pattern indicates the system volcanic springbelt. (2) geomorphological conditions affect the spatial distribution of springs, particularly factors of landform, geomorphological processes, and lithology. Anomalous spreading of springs found in the eastern part, is an example of the influence of geomorphological processes in the form of active volcanism that limits the availability of springs
\end{abstract}




\section{Pendahuluan}

Vulkan Merapi yang terletak di perbatasan Provinsi Daerah Istimewa Yogyakarta dan Jawa Tengah merupakan vulkan muda yang sangat aktif. Tingkat aktivitas yang tinggi dari Vulkan Merapi ini ditunjukkan oleh periode ulang letusan yang cukup singkat. Badan Geologi (2014) menjelaskan bahwa berdasarkan data yang tercatat sejak tahun 1600-an Vulkan Merapi telah meletus lebih dari 80 kali dengan rata-rata terjadi letusan setiap empat tahun. Sementara itu Andreastuti dkk (2006) menjelaskan, letusan Merapi terjadi sekali dalam kurun waktu 1-7 tahun. Erupsi Vulkan Merapi yang terjadi dari waktu ke waktu menghasilkan batuan penyusun yang didominasi oleh material berporositas tinggi. Material erupsi Vulkan Merapi memiliki karakteristik yang berselang-seling antara efusiva (aliran lava) dan eflata (bom, lapilli, tuf, dan abu vulkanis) (Simoen, 2001). Material penyusun berupa pasir dan kerikil memiliki porositas dan permeabilitas yang besar sehingga berperan penting dalam meresapkan dan menyimpan air sebagai airtanah.

Faktor relief yang dihasilkan dari ketinggian

Vulkan Merapi berpengaruh terhadap naiknya massa udara lembab sehingga banyak menyebabkan hujan orografis. Pada tipe vulkan strato seperti Merapi, hujan orografis terutama terjadi pada lereng yang terbuka terhadap arah angin (Verstappen, 2013). Hujan orografis yang jatuh pada material dengan permeabilitas dan porositas tinggi di wilayah recharge area akan banyak diresapkan sehingga menghasilkan potensi airtanah yang tinggi. Endapan lahar dan piroklastik merupakan akuifer yang baik dengan permeabilitas dan porositas tinggi yang apabila berkombinasi dengan curah hujan tinggi akan mempengaruhi tingginya potensi airtanah (Ashari, 2014).

Bagian selatan Vulkan Merapi merupakan lereng yang terbuka terhadap arah angin sehingga banyak terjadi hujan orografis. Disisi lain sebagai bagian yang banyak terdampak erupsi pada saat ini, bagian selatan Vulkan Merapi banyak mengalami pembaruan material yang memiliki permeabilitas dan porositas tinggi. Sebagai hasilnya, wilayah ini memiliki sumberdaya air tinggi yang ditunjukkan dengan keberadaan akuifer potensial dengan debit airtanah yang besar (Sutikno, Santosa, Widiyanto, Kurniawan, \& Purwanto, 2007)
Suplai airtanah yang melimpah pada akuifer vulkan muda seperti di bagian selatan Vulkan Merapi seringkali muncul sebagai mataair. Kondisi ini diakibatkan oleh pengaruh keberadaan tekuk lereng yang menyebabkan terpotongnya akuifer vulkanik. Persebaran mataair umumnya dijumpai secara melingkar di sekitar lereng dan kaki gunung api terutama pada daerah yang mempunyai perubahan lereng yang tajam karena pada bagian ini permukaan topografi memotong muka air tanah (tekuk lereng) sehingga membentuk spring belt (Santosa, 2006). Hal ini semakin menunjukkan tingginya potensi geohidrologis di bagian selatan Vulkan Merapi.

Potensi sumberdaya air yang tinggi merupakan salah satu faktor yang berpengaruh terhadap banyaknya penduduk yang bertempat tinggal di bagian selatan Vulkan Merapi. Pada tahun 2017 jumlah penduduk yang bertempat tinggal di desa-desa yang wilayahnya masuk dalam kawasan rawan bencana mencapai 47.347 jiwa (BPS Kabupaten Sleman, 2017a, 2017b, 2017c). Penghunian oleh penduduk bahkan telah berlangsung sejak masa lampau, dibuktikan dengan keberadaan candi yang telah dibangun pada sekitar abad ke-8 (Degroot, 2009). Namun demikian disisi lain bagian selatan Vulkan Merapi dari waktu ke waktu senantiasa menghadapi bencana erupsi. Bahkan pada peristiwa erupsi besar terakhir yang terjadi pada tahun 2010, bagian selatan Vulkan Merapi termasuk wilayah yang terdampak langsung dengan dilanda awan panas yang menimbulkan korban jiwa, kerusakan permukiman, infrastruktur, dan vegetasi yang terbakar (Badan Geologi, 2011). Selain kerugian tersebut, erupsi juga berdampak terhadap perubahan kondisi geomorfik di bagian selatan Vulkan Merapi (De Bélizal et al., 2013). Dengan banyaknya jumlah penduduk sekaligus masih adanya ancaman bencana pada masa mendatang, penelitian mengenai potensi mataair yang dapat dimanfaatkan baik untuk mencukupi kebutuhan sehari-hari maupun situasi darurat bencana sangat dibutuhkan.

Secara khusus penelitian ini bertujuan untuk menganalisis pola persebaran mataair dan pengaruh kondisi geomorfologis terhadap persebaran mataair di wilayah bagian selatan Vulkan Merapi. Diharapkan informasi mengenai persebaran mataair dapat bermanfaat untuk mempermudah akses sumberdaya air baik untuk mencukupi kebutuhan harian maupun dalam situasi darurat bencana. 


\section{Metode}

Penelitian ini menggunakan metode deskriptif dikombinasikan dengan metode eksploratif, dengan pendekatan geografi yaitu keruangan. Selain pendekatan keruangan, penelitian ini juga menekankan tema-tema geografi khususnya location, place, dan region dalam pembahasan untuk menunjukkan bagaimana pola persebaran mataair dan pengaruh kondisi geomorfologis terhadap persebaran mataair.

Populasi dalam penelitian ini adalah seluruh wilayah bagian selatan Vulkan Merapi. Penentuan lokasi pengamatan dilakukan dengan cara sistematik sampling yaitu membuat jalur-jalur pengamatan pada setiap satuan bentuklahan yang terdapat di daerah penelitian. Mengacu kepada keterangan Sutikno dkk (2007), Santosa (2006), maupun Simoen (2001) bahwa pemunculan mataair dijumpai pada satuan bentuklahan kaki lereng vulkan, kaki vulkan, maupun dataran kaki vulkan, maka penentuan sampel dalam penelitian ini dibatasi pada bentuklahan-bentuklahan tersebut.

Data-data dalam penelitian ini dikumpulkan melalui observasi, dokumentasi, dan studi pustaka. Observasi dilakukan untuk mendapatkan data lokasi mataair, debit mataair, kualitas mataair seperti suhu, $\mathrm{pH}$, daya hantar listrik, oksigen terlarut, dan salinitas. Dalam kegiatan observasi juga dilakukan pengambilan sampel mataair yang selanjutnya dilakukan uji laboratorium untuk mengetahui kualitas air berdasarkan parameter biologi dan kimia. Dokumentasi dilakukan dengan mengambil data kondisi geologis, penggunaan lahan, dan kependudukan dari beberapa dokumen yang dipublikasikan oleh lembaga terkait. Sedangkan studi pustaka dilakukan untuk memperoleh data dari publikasi buku maupun artikel jurnal khususnya dari Sutikno dkk (2007) dan Simoen (2001). Teknik Pengumpulan data ditunjukkan oleh Tabel 1.

Tabel 1. Teknik Pengumpulan Data dan Instrumen Pengumpulan Data

\begin{tabular}{|c|c|c|}
\hline Variabel & $\begin{array}{c}\text { Metode } \\
\text { pengumpulan Data }\end{array}$ & Instrumen / sumber data \\
\hline Lokasi mataair & Observasi & GPS \\
\hline \multirow{3}{*}{\begin{tabular}{ll}
\multicolumn{1}{c}{ Kondisi } \\
Geologis, dan \\
Geomorfologis, dan \\
penggunaan lahan \\
sekitar mataair
\end{tabular}} & Observasi & Kompas Geologi, Yallon, Lembar Observasi \\
\hline & Dokumentasi & $\begin{array}{l}\text { Peta Geologi Lembar Yogyakarta skala } \\
\text { 1:100.000 } \\
\text { Peta Rupabumi Indonesia Lembar Kaliurang dan } \\
\text { Pakem skala 1:25.000 }\end{array}$ \\
\hline & Studi Pustaka & $\begin{array}{l}\text { Sutikno dkk (2007), Verstappen (2013), Simoen } \\
\text { (2001) }\end{array}$ \\
\hline Debit mata air & Observasi & $\begin{array}{l}\text { wadah air, yallon, pelampung, roll meter, selang } \\
\text { plastik, yang digunakan untuk pengukuran debit } \\
\text { dengan metode volumetrik, apung, dan manning }\end{array}$ \\
\hline $\begin{array}{l}\text { Kondisi } \\
\text { kependudukan }\end{array}$ & Dokumentasi & BPS (2017) \\
\hline
\end{tabular}

Selanjutnya data dianalisis dengan kombinasi dari analisis deskriptif, analisis pencocokan (matching), dan analisis SIG. Untuk menunjukkan pola persebaran mataair digunakan analisis SIG dengan Average Nearest Neighbour Analysis. Analisis dilakukan dengan menggunakan perangkat ArcGIS 10.3 dengan memperhatikan skor $Z$ dan nilai $P$. Kurniati dkk (2016) menjelaskan nilai $z$-score merupakan indikator dalam penentuan jenis pola persebaran. Aurita dan Purwantara (2017) telah menggunakan analisis ini untuk menentukan pola persebaran mataair di Lereng Barat Vulkan Merapi. Dalam analisis ini terdapat tiga jenis pola persebaran yaitu pola mengelompok (clustered) ditunjukkan dengan nilai $z$-score yang negatif, kemudian pola seragam (dispered) ditunjukkan dengan $z$-score yang positif, serta pola acak (random) ditunjukkan dengan z-score yang berada di kisaran angka nol. Analisis pencocokan (matching) digunakan untuk menjelaskan kualitas air hasil pengukuran lapangan dengan kriteria baku mutu air yang telah diatur dalam PP RI No. 82 Tahun 2001 dan Permenkes RI No 32 Tahun 2017. Analisis 
pencocokan juga dilakukan untuk menentukan klasifikasi tipe dan debit mataair (Purnama, 2010). Analisis keruangan didukung dengan analisis deskriptif digunakan untuk mengetahui hubungan spasial antara persebaran mataair dengan persebaran satuan bentuklahan di lapangan serta proses-proses geomorfik yang berlangsung pada satuan bentuklahan tersebut. Analisis ini bersifat saling melengkapi dengan analisis SIG. Gambar 1 berikut ini menunjukkan diagram alir penelitian.

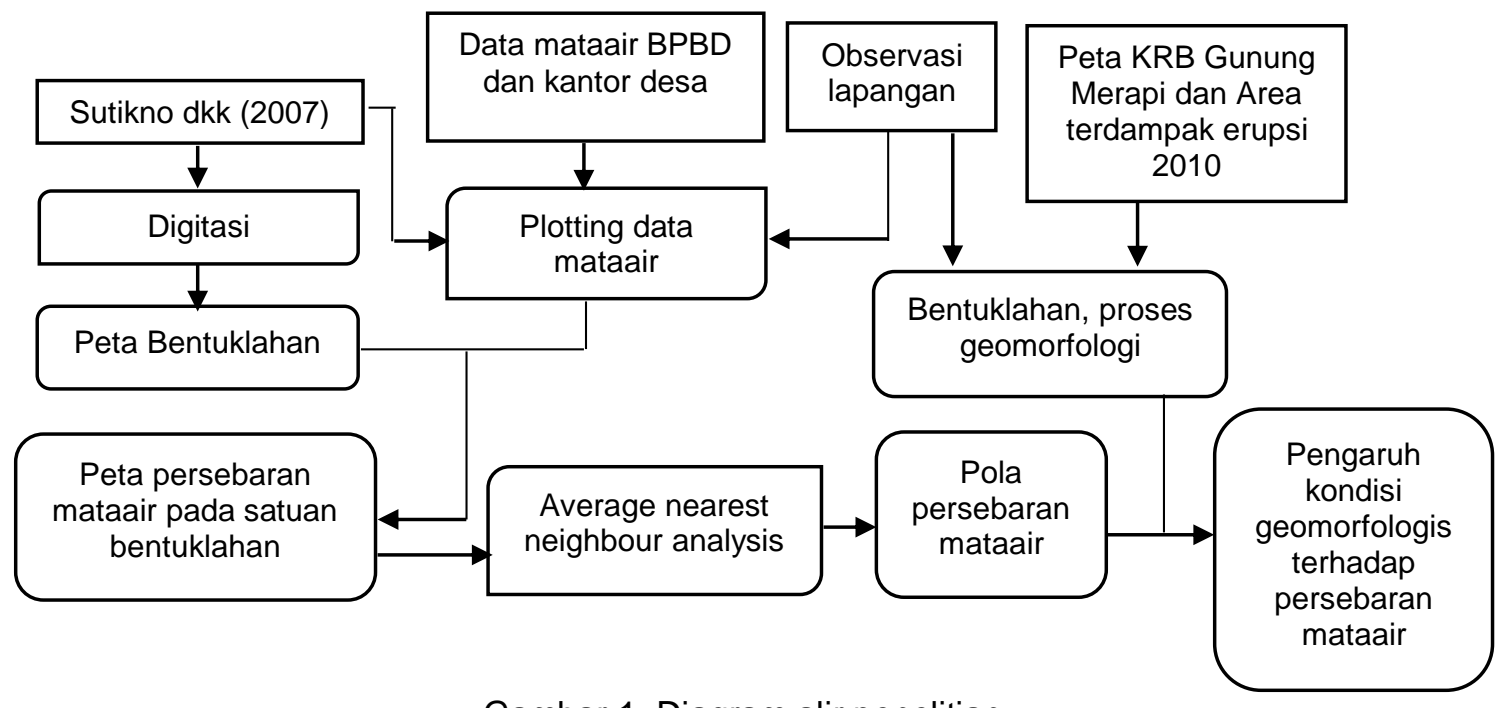

Gambar 1. Diagram alir penelitian

\section{Hasil dan pembahasan \\ Daerah Penelitian}

Penelitian ini dilakukan di bagian selatan Vulkan Merapi yaitu meliputi wilayah yang terletak diantara lembah Sungai Krasak di bagian barat hingga lembah Sungai Gendol di bagian timur. Secara astronomis daerah penelitian terletak pada 430156 MT hingga 441484 MT serta $9154934 \mathrm{MU}$ hingga $9166320 \mathrm{MU}$ dalam koordinat UTM zona $49 \mathrm{~S}$. secara administratif daerah penelitian meliputi Kecamatan Turi, Kecamatan Pakem, dan Kecamatan Cangkringan. Daerah penelitian berbatasan dengan wilayah Provinsi Jawa Tengah di bagian barat, utara, dan timur yaitu Kabupaten Magelang, Kabupaten Boyolali, dan Kabupaten Klaten. Adapun di bagian selatan daerah penelitian dibatasi oleh wilayah Kabupaten Sleman (Gambar 2). Luas daerah penelitian secara keseluruhan adalah $61,13 \mathrm{~km}^{2}$.

Secara geomorfologis daerah penelitian merupakan bentuklahan vulkanik yang terbagi menjadi beberapa satuan bentuklahan yang lebih rinci. Nurhadi dkk (2017) menjelaskan bahwa Vulkan Merapi merupakan vulkan strato dan secara geomorfologis vulkan strato yang masih aktif memiliki bentuklahan yang sangat kompleks dari puncak hingga bagian bawahnya. Morfologi vulkan strato setidaknya terbagi menjadi tiga segmen lereng yaitu bagian atas, tengah, dan bawah. Bagian atas terbentuk oleh abu atau klastik dari hancuran sumbat lava, jatuhan, atau longsor, yang dipengaruhi oleh tenaga gravitasi; bagian tengah terbentuk oleh pengendapan material lahar, sedangkan bagian bawah terbentuk oleh endapan fluvial. Masing-masing bagian dipisahkan oleh tekuk lereng (Verstappen, 2013). Secara rinci morfologi vulkan strato Merapi terdiri dari kepundan, kerucut vulkan, lereng vulkan, kaki vulkan, dataran fluvio kaki vulkan, dan dataran fluviovulkan (Simoen, 2001; Sutikno et al., 2007).

Faktor geomorfologi akan banyak mendapat perhatian dalam penelitian ini karena berpengaruh terhadap keterdapatan dan persebaran mataair. Ashari (2017) menjelaskan bahwa potensi sumberdaya air berkaitan dengan faktor kondisi geomorfologi. Sebagai contoh keberadaan tekuk lereng pada bentanglahan vulkanik merupakan faktor yang berpengaruh terhadap pemunculan mataair. Karena tekuk lereng terdapat dalam pola melingkar terhadap morfologi kerucut vulkan maka pemunculan mataair juga mengikuti pola tersebut sehingga dikenal sebagai sabuk mataair.

Selanjutnya secara geologis daerah penelitian tersusun oleh material Endapan Gunungapi Merapi Muda (Qmi) dan Endapan Gunungapi Merapi Tua (Qmo). Endapan Gunungapi Merapi Muda berupa tuf, abu, breksi, 
aglomerat dan leleran lava tak terpisahkan, sedangkan Endapan Gunungapi Merapi Tua berupa breksi aglomerat dan leleran lava, termasuk andesit dan basal mengandung olivin (Raharjo, Sukandarrumidi, \& Rosidi, 1995). Endapan Gunungapi Merapi Tua hanya sedikit dijumpai di daerah penelitian, sebaliknya Endapan Gunungapi Merapi Muda sangat mendominasi. Sifat material Endapan Gunungapi Merapi Muda yang lebih permeabel dan porus berpengaruh terhadap keterdapatan sumberdaya air di wilayah ini. Sutikno dkk (2007) menjelaskan bahwa endapan volkanik Merapi muda membentuk dua kelompok akuifer yang terbagi ke dalam tujuh satuan hidrogeologi mulai dari akuifer berpoduktivitas tinggi hingga sedang, dengan penyebaran luas hingga terbatas. Sedangkan material endapan volkanik Kwarter Tua seperti bukit turgo dan plawangan termasuk ke dalam daerah non akuifer.

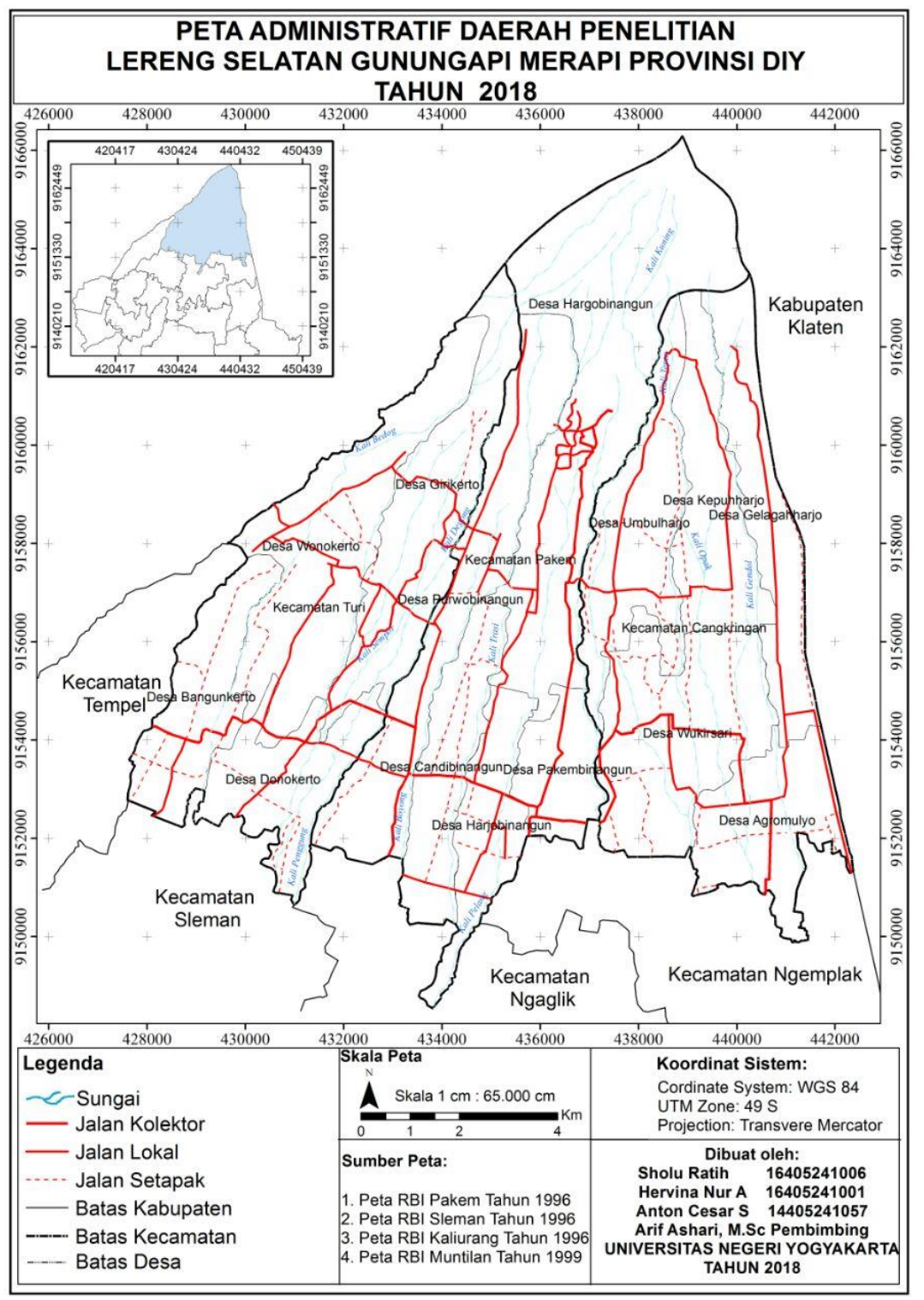

Gambar 2. Peta Administratif Daerah Penelitian

Faktor iklim yang ditandai dengan curah hujan tinggi di daerah penelitian juga berpengaruh terhadap potensi sumberdaya airtanah. Sutikno dkk (2007) berdasarkan analisis data hujan antara tahun 1987 hingga 1996 menunjukkan bahwa pada satuan bentuklahan lereng gunungapi curah hujan mencapai $1734 \mathrm{~mm}$, kaki gunungapi 1550 $\mathrm{mm}$, dataran kaki gununungapi $1186 \mathrm{~mm}$, dan dataran fluvial gunungapi $1328 \mathrm{~mm}$. Curah hujan tertinggi dijumpai pada satuan bentuklahan lereng gunungapi dengan material berpermeabilitas tinggi menyebabkan banyak terjadi resapan air 
hujan. Konsentrasi mataair pada satuan bentuklahan lereng vulkan dan kaki vulkan menunjukkan bahwa infiltrasi terjadi secara intensif di bagian atas.

Penggunaan lahan di daerah penelitian bervariasi yaitu terdiri dari hutan, semak belukar, kebun campuran, tegalan, sawah, dan permukiman. Penggunaan lahan berupa kebun campuran, tegalan, dan sawah terdapat di wilayah yang ditempati oleh penduduk. Di wilayah selatan Vulkan Merapi yang termasuk dalam wilayah penelitian ini, jumlah penduduk tertinggi terdapat di Kecamatan Pakem yaitu sebanyak 37.733 jiwa, kemudian Kecamatan Turi sebanyak 34.233 jiwa, dan Kecamatan Cangkringan sebanyak 29.321 jiwa. Kepadatan penduduk tertinggi juga terdapat di Kecamatan Pakem yaitu 861 jiwa $/ \mathrm{km}^{2}$, kemudian Kecamatan Turi $794 \mathrm{jiwa} / \mathrm{km}^{2}$, dan Kecamatan Cangkringan $611 \mathrm{jiwa} / \mathrm{km}^{2}$.

Pola persebaran mataair berdasarkan satuan bentuklahan di bagian selatan Vulkan Merapi

Keterdapatan mataair merupakan potensi sumberdaya alam yang sangat penting bagi masyarakat yang hidup di bawah bayang-bayang gunung berapi, salah satunya yakni masyarakat yang tinggal di lereng selatan Vulkan Merapi. Walaupun memiliki potensi bahaya yang cukup besar, wilayah bagian selatan Vulkan Merapi menyimpan banyak potensi sumberdaya alam yaitu sumberdaya hayati, sumberdaya lahan, sumberdaya mineral, dan sumberdaya air (Sutikno et al., 2007). Sumberdaya air di wilayah ini selain jumlahnya banyak juga memiliki kualitas yang baik.

Kondisi lingkungan fisik yang mendukung ketersediaan air seperti elevasi yang tinggi, material berporositas dan berpermeabilitas baik, serta penggunaan lahan yang mendukung peresapan air ke dalam tanah menyebabkan daerah ini menjadi wilayah produksi airtanah yang baik. Selain menghasilkan potensi airtanah yang tinggi di wilayah yang berdekatan dengan area resapan. produksi airtanah dari wilayah ini juga menjadi penyangga bagi daerah yang berada di bawah seperti Yogyakarta dan Bantul. Salah satu perwujudan dari potensi sumberdaya air di wilayah selatan Vulkan Merapi adalah mataair.

Berkaitan persebaran mataair, Santosa (2006) menjelaskan bahwa kebanyakan mataair yang berada di tubuh gunungapi dijumpai pada perubahan satuan bentuklahan. Terdapat tiga satuan pemunculan mataair, yaitu satuan mataair pada volcanic slope, satuan mataair volcanic foot, dan satuan mataair volcanic foot plain. Pada satuan volcanic slope, mataair muncul karena faktor kemiringan lereng yang cukup besar yang menyebabkan air hujan hanya dapat merembes masuk ke dalam formasi piroklastis di atas formasi lava flow yang kedap air. Pada bagian ini, pemunculan mataair tergantung luas hutan sebagai penahan air hujan serta lapisan tanah yang umumnya sangat tipis dari hasil pelapukan piroklastis atau lava. Debit umumnya relatif kecil, kecuali adanya rekahan (fracture) pada lava flow yang bergabung menjadi aliran yang cukup besar dan muncul di ujung volcanic slope atau bahkan di satuan volcanic foot. Selanjutnya pada satuan kaki volkan dijumpai jalur mataair (spring belt) yang terdapat pada ujung aliran lava Merapi Muda di bagian Barat dan ujung aliran lava Merapi Tua di bagian timur. Pada satuan volcanic plain juga banyak dijumpai mataair yang disebabkan oleh perbedaan kemiringan karena perubahan morfologi yang disebabkan oleh perubahan tekstur batuan yang kasar ke tekstur halus. Berdasarkan kondisi tersebut maka persebaran mataair di Vulkan Merapi muncul sebagai pola sabuk mataair pada perubahan satuan unit bentuklahan.

Sementara itu, Simoen (2001) menjelaskan bahwa bentuklahan pada vulkan strato terdiri dari menjadi kerucut vulkan, lereng vulkan, kaki vulkan, dataran kaki vulkan, dan dataran fluviovulkan. Masing-masing bagian tersebut ditandai oleh tekuk lereng. Keberadaan tekuk lereng ini menyebabkan terjadi pemunculan mataair yang membentuk pola sabuk mataair mengelilingi kerucut vulkan.

Berdasarkan keterangan dari Santosa (2006) dan Simoen (2001) diatas, pengamatan mataair yang kami lakukan di daerah penelitian terutama difokuskan pada wilayah perubahan bentuklahan, yaitu perubahan dari lereng gunungapi ke kaki gunungapi dan dari kaki gunungapi ke dataran kaki gunungapi. Hal ini didasari pada asumsi bahwa wilayah perubahan bentuklahan merupakan wilayah konsentrasi mataair. Pengamatan dilakukan pada 30 sampel mataair yang terdapat di Kecamatan Turi, Pakem, dan Cangkringan (Tabel 2). Hasil analisis menunjukkan bahwa persebaran mataair di daerah penelitian berpola mengelompok. Hasil analisis average nearest neighbour menunjukkan skor $Z$ ( $Z$-score) yang negatif yaitu $-3,66$ dengan nilai $P$ ( $p$-value) 0,000025 . Angka ini menunjukkan 
bahwa pola persebaran mataair di daerah penelitian bersifat sangat mengelompok. Apabila diperhatikan pada peta hasil plotting lokasi (koordinat) mataair, dapat dilihat bahwa pola mengelompok ini dijumpai sebagai jalur memanjang yang mengindikasikan pola sabuk mataair. Persebaran mataair umumnya terletak di dekat tekuk lereng. Namun demikian terdapat pula mataair yang lokasinya terpisah dari kelompok sabuk mataair ini (Gambar 3).

Tabel 2. Mataair di Daerah Penelitian

\begin{tabular}{|c|c|c|c|}
\hline No & Nama mataair & Koordinat lokasi & Debit $(\mathrm{l} / \mathrm{s})$ \\
\hline 1 & Kemirikebo & $110^{\circ} 24^{\prime} 23.353^{\prime \prime}$ E, $7^{\circ} 36^{\prime} 46.353^{\prime \prime} \mathrm{S}$ & 0,35 \\
\hline 2 & Kemirikebo II & $110^{\circ} 24^{\prime} 6.313^{\prime \prime} \mathrm{E}, 7^{\circ} 36^{\prime} 49.130^{\prime \prime} \mathrm{S}$ & 0,15 \\
\hline 3 & Randusari & $110^{\circ} 24^{\prime} 9.758^{\prime \prime} \mathrm{E}, 7^{\circ} 37^{\prime} 46.641^{\prime \prime} \mathrm{S}$ & 0,21 \\
\hline 4 & Karangnongko & $110^{\circ} 24^{\prime} 9.758^{\prime \prime}$ E, $7^{\circ} 37^{\prime} 46.641^{\prime \prime} \mathrm{S}$ & 5 \\
\hline 5 & Kemirikebo III & $110^{\circ} 24^{\prime} 9.977^{\prime \prime}$ E, $7^{\circ} 36^{\prime} 43.014^{\prime \prime} \mathrm{S}$ & 0,1 \\
\hline 6 & Umbul Temanten & $110^{\circ} 26^{\prime} 35.790^{\prime \prime} \mathrm{E}, 7^{\circ} 35^{\prime} 40.779^{\prime \prime} \mathrm{S}$ & 1 \\
\hline 7 & Sendang Pancuran & $110^{\circ} 23^{\prime} 49.593^{\prime \prime} \mathrm{E}, 7^{\circ} 35^{\prime} 46.586^{\prime \prime} \mathrm{S}$ & 0,1 \\
\hline 8 & Tunggul Arum & $110^{\circ} 23^{\prime} 48.383^{\prime \prime} \mathrm{E}, 7^{\circ} 35^{\prime} 48.311^{\prime \prime} \mathrm{S}$ & 1 \\
\hline 9 & Merti Bumi & $110^{\circ} 23^{\prime} 43.095^{\prime \prime} \mathrm{E}, 7^{\circ} 35^{\prime} 48.824^{\prime \prime} \mathrm{S}$ & 0,64 \\
\hline 10 & Benteng Celeng & 110²4'28.289" E, 7³5’5.806" S & 0,30 \\
\hline 11 & Kedung Cuwo & $110^{\circ} 23^{\prime} 37.689^{\prime \prime} \mathrm{E}, 7^{\circ} 36^{\prime} 4.121^{\prime \prime} \mathrm{S}$ & 2 \\
\hline 12 & Bendung Suro & $110^{\circ} 23^{\prime} 10.381^{\prime \prime} \mathrm{E}, 7^{\circ} 35^{\prime} 58.710^{\prime \prime} \mathrm{S}$ & 0,8 \\
\hline 13 & Goa Lawa & $110^{\circ} 23^{\prime} 29.776^{\prime \prime} \mathrm{E}, 7^{\circ} 36^{\prime} 37.813^{\prime \prime} \mathrm{S}$ & 1,2 \\
\hline 14 & Ledok Lempong & $110^{\circ} 22^{\prime} 52.900^{\prime \prime} \mathrm{E}, 7^{\circ} 36^{\prime} 59.024^{\prime \prime} \mathrm{S}$ & 0,7 \\
\hline 15 & Sendang Jambon & $110^{\circ} 23^{\prime} 39.349^{\prime \prime} \mathrm{E}, 7^{\circ} 37^{\prime} 1.406^{\prime \prime} \mathrm{S}$ & 3 \\
\hline 16 & Ledok Ipik & $110^{\circ} 24^{\prime} 13.815^{\prime \prime} \mathrm{E}, 7^{\circ} 36^{\prime} 52.924^{\prime \prime} \mathrm{S}$ & 0,6 \\
\hline 17 & Jobin & $110^{\circ} 24^{\prime} 11.738^{\prime \prime} \mathrm{E}, 7^{\circ} 36^{\prime} 56.023^{\prime \prime} \mathrm{S}$ & 0,2 \\
\hline 18 & Ledok Mincon & $110^{\circ} 24^{\prime} 9.921^{\prime \prime} \mathrm{E}, 7^{\circ} 36^{\prime} 58.346^{\prime \prime} \mathrm{S}$ & 0,4 \\
\hline 19 & Sumber Andong & $110^{\circ} 24^{\prime} 1.580^{\prime \prime} \mathrm{E}, 7^{\circ} 37^{\prime} 35.813^{\prime \prime} \mathrm{S}$ & 3,1 \\
\hline 20 & Sumber Pucung & $110^{\circ} 23^{\prime} 58.994^{\prime \prime} \mathrm{E}, 7^{\circ} 37^{\prime} 31.932^{\prime \prime} \mathrm{S}$ & 2,1 \\
\hline 21 & Sumber Cuwo & $110^{\circ} 24^{\prime} 0.537^{\prime \prime} \mathrm{E}, 7^{\circ} 37^{\prime} 40.464^{\prime \prime} \mathrm{S}$ & 1,9 \\
\hline 22 & Umbul Candi & $110^{\circ} 24^{\prime} 8.286^{\prime \prime} \mathrm{E}, 7^{\circ} 37^{\prime} 51.087^{\prime \prime} \mathrm{S}$ & 0,8 \\
\hline 23 & Kletak & $110^{\circ} 25^{\prime} 9.172^{\prime \prime} \mathrm{E}, 7^{\circ} 35^{\prime} 22.175^{\prime \prime} \mathrm{S}$ & 0,24 \\
\hline 24 & Madoan & $110^{\circ} 24^{\prime} 40.094^{\prime \prime} \mathrm{E}, 7^{\circ} 36^{\prime} 10.728^{\prime \prime} \mathrm{S}$ & 0,7 \\
\hline 25 & Kratuan & $110^{\circ} 24^{\prime} 19.915^{\prime \prime} \mathrm{E}, 7^{\circ} 37^{\prime} 6.116^{\prime \prime} \mathrm{S}$ & 0,9 \\
\hline 26 & Tawang rejo & $110^{\circ} 24^{\prime} 7.410^{\prime \prime} \mathrm{E}, 7^{\circ} 37^{\prime} 57.172^{\prime \prime} \mathrm{S}$ & 1 \\
\hline 27 & Kemiri & $110^{\circ} 25^{\prime} 10.256^{\prime \prime} \mathrm{E}, 7^{\circ} 37^{\prime} 19.779^{\prime \prime} \mathrm{S}$ & 0,3 \\
\hline 28 & Guwa Lava & 110²3'17.327" E, 7³6’9.339" S & 1,6 \\
\hline 29 & Bebeng & $110^{\circ} 28^{\prime} 10.122^{\prime \prime} \mathrm{E}, 7^{\circ} 39^{\prime} 33.916^{\prime \prime} \mathrm{S}$ & 1,1 \\
\hline 30 & Gambiran & $110^{\circ} 25^{\prime} 35.470^{\prime \prime} \mathrm{E}, 7^{\circ} 39^{\prime} 47.932^{\prime \prime} \mathrm{S}$ & 0,45 \\
\hline 31 & Pakem & $110^{\circ} 25^{\prime} 12.772 " \mathrm{E}, 7^{\circ} 40^{\prime} 8.450^{\prime \prime} \mathrm{S}$ & 0,9 \\
\hline
\end{tabular}

Sumber: Data Lapangan (2018), BPBD (2011), Data Monografi Desa (2017)

Mataair di daerah penelitian memiliki debit yang bervariasi sebagaimana ditunjukkan oleh Tabel 2. Berdasarkan debitnya, Meinzer mengklasifikasikan mataair ke dalam 8 kelas yaitu kelas I hingga kelas VIII. Debit mataair berturutturut dari kelas I hingga kelas VIII adalah: kelas I debit $>10 \mathrm{~m}^{3} /$ detik, kelas II debit $1-10 \mathrm{~m}^{3} /$ detik, kelas III debit $0,1-1 \mathrm{~m}^{3} /$ detik, kelas IV debit 10 100 liter/detik, kelas $V$ debit $1-10$ liter/detik, kelas VI $0,1-1$ liter/detik, kelas VII debit $10-100$ $\mathrm{ml} /$ detik, dan kelas VIII debit $<10 \mathrm{ml} /$ detik
(Purnama, 2010). Berdasarkan klasifikasi tersebut mataair di daerah penelitian termasuk dalam kelas VI dan kelas V. Debit mataair terbesar adalah 5 liter/detik di Mataair Karangnongko masih tergolong dalam kelas VI dan debit terkecil adalah 0,1 liter/detik di Mataair Sendang Pancuran masih tergolong dalam kelas VII. Mataair di daerah penelitian umumnya telah dimanfaatkan oleh masyarakat untuk kebutuhan domestik (Gambar 4), terutama mataair dengan debit yang besar. 
Pola persebaran yang membentuk sabuk mataair di daerah penelitan merupakan ciri dari vulkan muda. Pola persebaran mataair pada morfologi vulkan strato muda seperti Merapi memang masih nampak jelas sebagai sabuk mataair (Sutikno et al., 2007). Hasil yang diperoleh di daerah penelitian ini memiliki persamaan dan perbedaan apabila dibandingkan dengan hasil penelitian terdahulu misalnya dari Ashari (2014), Aurita dan Purwantara (2017), atau Santosa (2006) yang juga dilakukan pada bentanglahan vulkanik. Santosa (2006) menunjukkan perkembangan bentuklahan vulkanik di bagian Vulkan Lawu tua berpengaruh terhadap pola sabuk mataair yang menjadi lebih tidak teratur. Ashari (2014) menjumpai gejala persebaran mataair yang lebih teratur di lereng timur Vulkan Sindoro karena pengaruh proses erosi dan gerakan massa belum berlangsung intensif dalam mendenudasi bentuklahan. Sementara itu Aurita dan Purwantara (2017) yang melakukan penelitian di sisi barat Vulkan Merapi menjumpai pola yang mengelompok namun tidak dalam pola sabuk mataair yang ideal melainkan mengelompok pada lembah sungai radial yang terjadi akibat pemotongan akuifer pada lembah sungai tersebut.

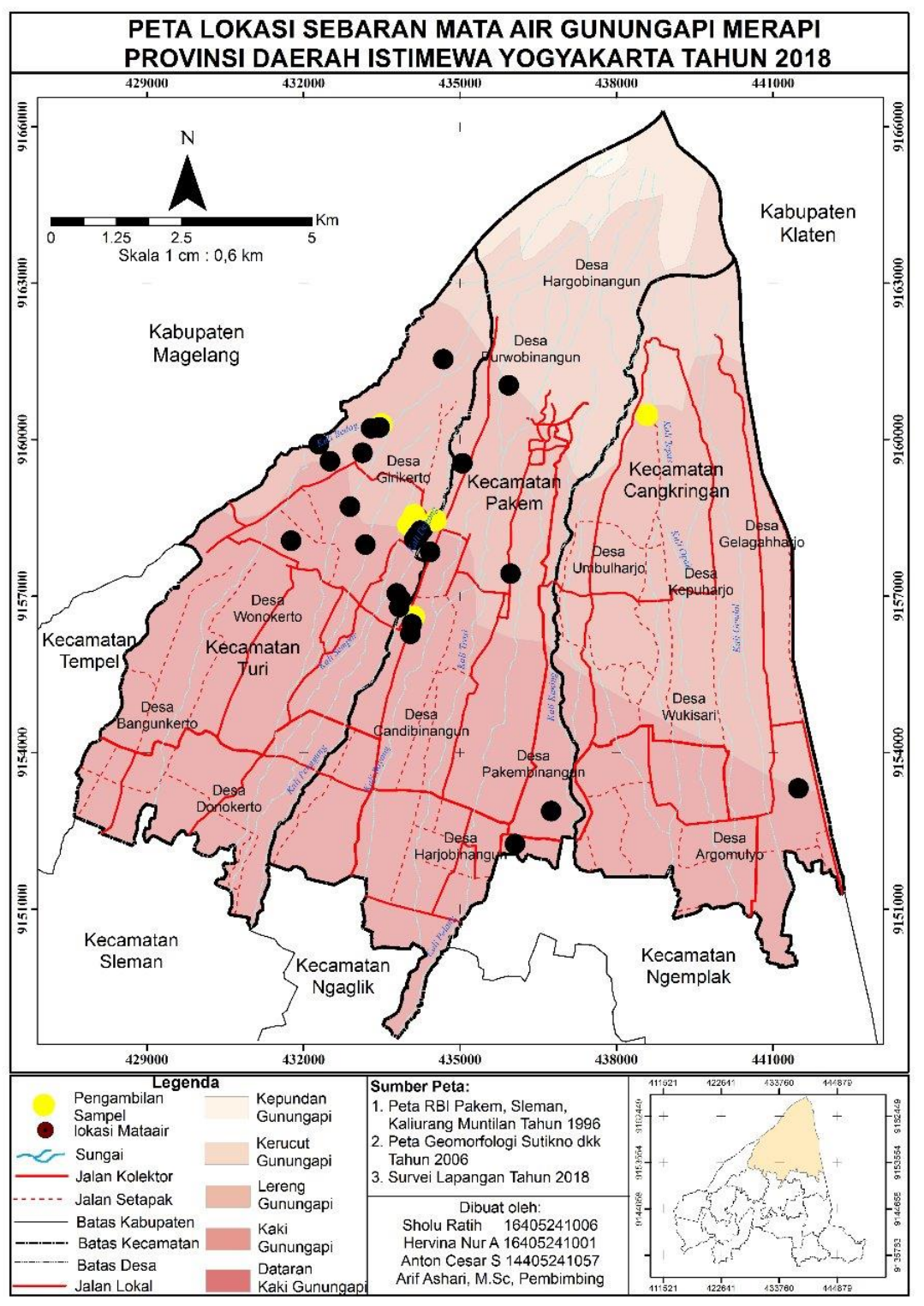

Gambar 2. Peta persebaran mataair di bagian selatan Vulkan Merapi 
Temuan dari penelitian ini yang menunjukkan pola sabuk mataair yang cenderung teratur sama dengan di lereng timur Vulkan Sindoro (Ashari, 2014) sebagai vulkan muda yang belum banyak terpengaruh oleh proses eksogen. Dilihat dari aktivitasnya, Vulkan Merapi bahkan jauh lebih aktif sehingga pengaruh proses vulkanisme lebih dominan daripada proses eksogen dalam mempengaruhi perkembangan bentuklahan. Hal inilah yang mempengaruhi pola persebaran mataair yang cenderung teratur di daerah penelitian, berbeda dengan di Vulkan Lawu (Santosa, 2006) yang bervariasi antara bagian Lawu Muda dan Lawu Tua. Bagian Lawu Muda yang relatif masih teratur juga menunjukkan kesamaan hasil dengan penelitian ini. Namun bagian Lawu Tua yang telah terdenudasi secara intensif menghasilkan pola yang tidak teratur. Perbandingan yang menarik justru terjadi antara bagian selatan Vulkan Merapi dari hasil penelitian ini dengan bagian barat Vulkan Merapi (Aurita \& Purwantara, 2017). Walaupun terdapat pada vulkan yang sama namun perbedaan perkembangan bentuklahan antara bagian barat dan bagian selatan berpengaruh terhadap perbedaan pola sabuk mataair. Bagian selatan Vulkan Merapi merupakan wilayah yang paling terdampak erupsi hingga saat ini. Hasil aktivitas vulkanik yang masih kuat di bagian selatan banyak berpengaruh terhadap pola persebaran mataair yang berbeda dengan bagian barat, walaupun perbedaannya tidak terlalu mencolok karena masih sama-sama berpola mengelompok.

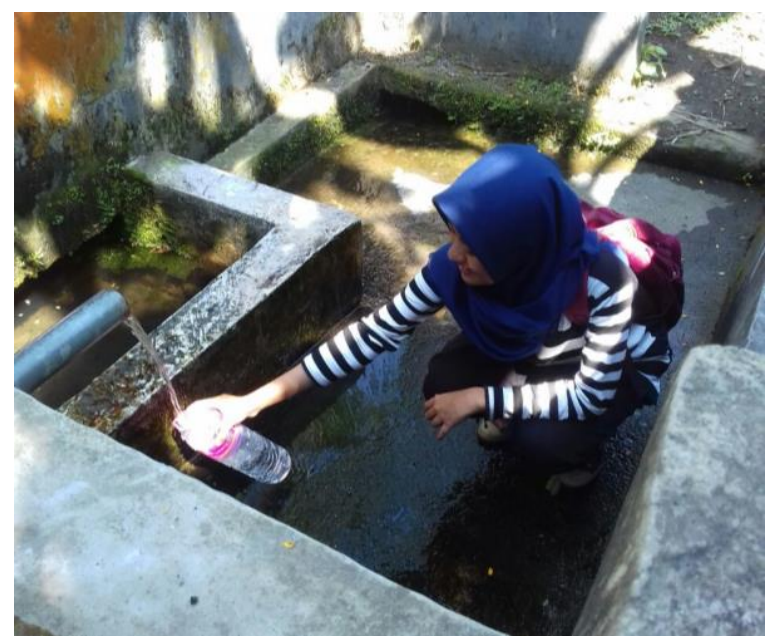

B
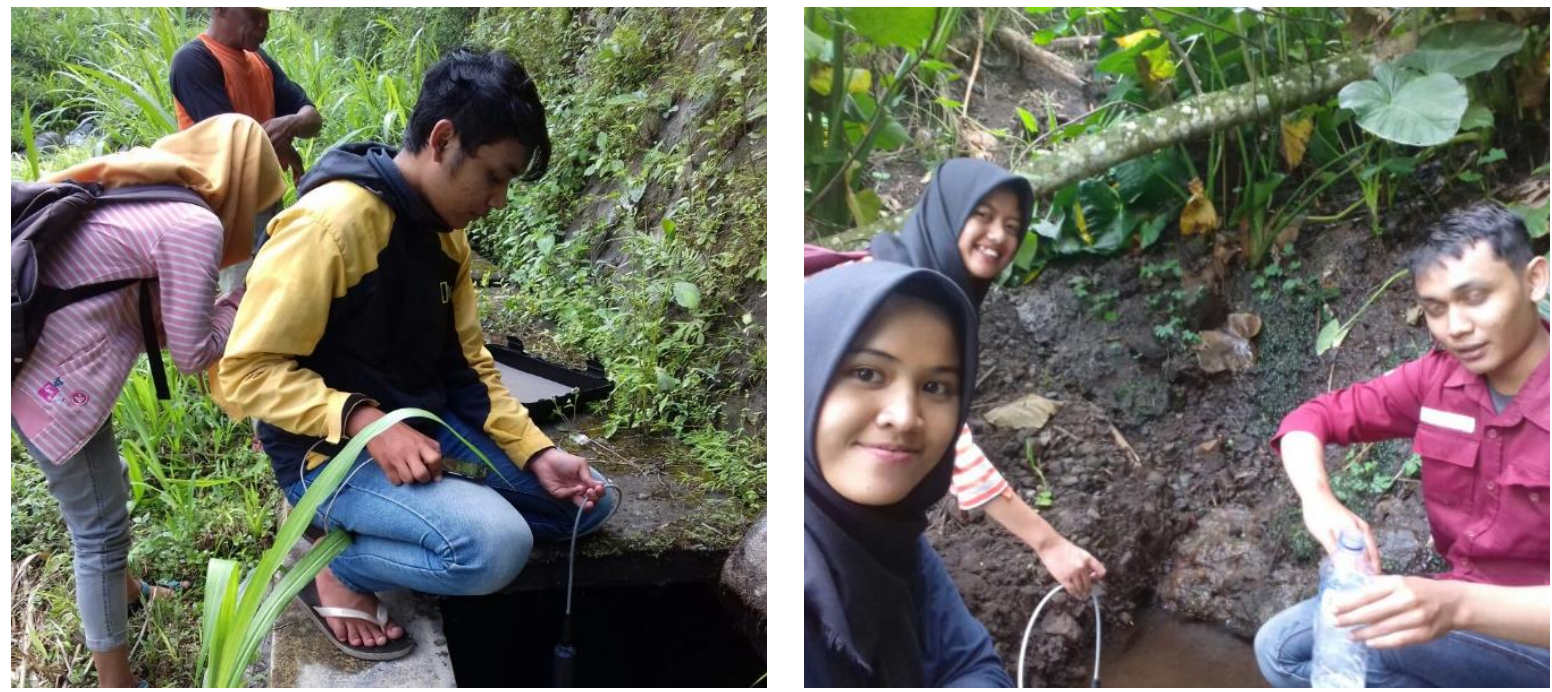

D

Gambar 4. Sampel mataair di daerah penelitian. A: Mataair Kemirikebo I, B: Mataair Kemirikebo II, C: Mataair Karangnongko I, D: Mataair Karangnongko II (Sumber: data lapangan, 2018) 
Lebih lanjut dengan memperhatikan peta persebaran mataair hasil dari plotting lokasi mataair di daerah penelitian, diketahui bahwa konsentrasi mataair berada di satuan bentuk lahan antara kaki gunung dan dataran kaki gunung. Hal tersebut sesuai dengan keterangan yang disampaikan Simoen (2001) yaitu sabuk mataair yang paling tampak adalah yang berada pada peralihan unit morfologi kaki gunungapi dan unit dataran fluvial kaki gunungapi. Mataairmataair terletak di antara kaki vulkan dan dataran kaki vulkan dikarenakan pemunculan mataair itu terjadi karena pemotongan aliran air tanah. Oleh karenanya, air tanah tersebut muncul ke permukaan sebagai mataair, sebagaimana juga yang disampaikan oleh Santosa (2006).

\section{Pengaruh kondisi geomorfologis terhadap} persebaran mataair

Pembicaraan mengenai kondisi geomorfologis tidak terlepas dari aspek pembahasan dalam geomorfologi. Terdapat beberapa sudut pandang dalam menentukan aspek kajian geomorfologi (Pramono \& Ashari, 2014), dalam penelitian ini kami mengacu kepada aspek kajian geografi yang dijelaskan oleh Verstappen (1983) yaitu meliputi bentuklahan, genesis, proses, dan lingkungan

Kondisi geomorfologi di daerah penelitian sebagaimana telah dijelaskan pada bagian sebelumnya merupakan bentuklahan vulkan strato muda yang dicirikan oleh beberapa segmen lereng yang dibatasi oleh tekuk lereng. Secara geomorfologis Vulkan Merapi memiliki genesis, material, dan struktur yang unik (Sutikno et al., 2007). Bentuklahan di bagian selatan Vulkan Merapi, khususnya di daerah rawan bencana terdiri dari kepundan, kerucut gunungapi, lereng gunungapi, dan kaki gunungapi (Ashari, 2017).

Pengaruh kondisi geomorfologi terhadap persebaran mataair yang paling utama adalah terbentuknya sistem sabuk mataair yang berkaitan dengan keberadaan tekuk lereng. Sebagaimana telah dijelaskan pada bagian sebelumnya bahwa pola persebaran mataair pada morfologi vulkan strato muda seperti Merapi memang masih nampak jelas sebagai sabuk mataair (Sutikno et al., 2007). Hal ini merupakan gejala yang umum terjadi pada vulkan muda yang belum banyak mengalami denudasi bentuklahan akibat proses erosi dan gerakan massa (Ashari, 2014). Tekuk lereng sebagai wilayah perubahan bentuklahan merupakan wilayah konsentrasi mataair. Hal ini terjadi karena keberadaan tekuk lereng menyebabkan terpotongnya akuifer sehingga menghasilkan pemunculan mataair. Di daerah penelitian sabuk mataair terutama dijumpai pada peralihan antara bentuklahan lereng gunungapi dengan kaki gunungapi serta antara bentuklahan kaki gunungapi dengan dataran kaki gunungapi.

Selain faktor bentuklahan proses geomorfologi juga berpengaruh terhadap persebaran mataair. Pada peta persebaran mataair yang telah disusun dalam penelitian ini dapat diketahui bahwa persebaran mataair terutama terkonsentrasi pada sisi barat daerah penelitian terutama di Kecamatan Turi. Adapun pada sisi timur yang termasuk dalam wilayah Kecamatan Cangkringan keterdapatan mataair sangat terbatas. Hal ini menjadi temuan yang sangat menarik bahwa ternyata terdapat perbedaan antara sisi barat dengan sisi timur pada bagian selatan Vulkan Merapi.

Dalam riwayat erupsi Vulkan Merapi, bagian baratdaya merupakan wilayah yang banyak terkena dampak erupsi pada masa lampau (Andreastuti et al., 2006). Namun demikian pada masa sekarang lereng barat terutama sisi timur di sekitar lembah Sungai Gendol lebih banyak terkena dampak erupsi seperti ditunjukkan dalam peta kawasan rawan bencana dan area terdampak erupsi 2010 (Badan Geologi, 2011). Sisi timur dari bagian selatan Vulkan Merapi yang masih banyak terdampak erupsi pada saat ini tertutup oleh material yang tebal dari hasil erupsi. Tebalnya material ini diduga menjadi salah satu faktor yang berpengaruh terhadap tidak adanya mataair di sisi timur. Sementara itu sisi barat yang tidak terdampak langsung oleh erupsi berupa pengendapan material piroklastik baru yang tebal, relatif mulai mengalami proses denudasi walaupun masih pada tahap awal. Proses geomorfologi di sisi barat ini lebih mendukung untuk terdapatnya pemunculan mataair.

Dugaan ini diperkuat oleh penjelasan Santosa (2006) bahwa mataair muncul tergantung lapisan tanah yang umumnya sangat tipis yang terbentuk karena pelapukan piroklastis atau aliran-aliran lava yang telah mengalami pelapukan. Sisi timur dari bagian selatan Vulkan Merapi karena terdampak langsung oleh letusan tahun 2010 mendapatkan material yang tebal dari endapan piroklastik. Oleh karena faktor ini maka 
tekuk lereng di sisi timur relatif lebih halus perubahan kemiringannya daripada sisi barat, dan sekaligus menghambat terjadinya pemunculan mataair karena tidak adanya pemotongan akuifer. Berdasarkan hasil wawancara yang dilakukan kepada perangkat desa di Kecamatan Cangkringan juga diketahui bahwa sebelum erupsi tahun 2010 di wilayah tersebut juga terdapat mataair namun kemudian menghilang pasca terjadinya erupsi.

Dilihat dari litologi sisi timur yang homogen yaitu berupa endapan gunungapi Merapi Muda, nampaknya fenomena anomali berupa tidak adanya mataair pada tekuk lereng sisi timur ini lebih disebabkan oleh pengaruh erupsi daripada faktor perbedaan litologi. Kondisi ini berbeda dengan yang ditemukan oleh Simoen (2001) di lereng timur dan tenggara Vulkan Merapi khususnya pada dataran fluviovulkan yang berada di wilayah bawah. Dalam penelitiannya Simoen (2001) menemukan bahwa di lereng timur dan tenggara Gunungapi Merapi keberadaan mataair tidak tampak tegas (absen) karena faktor perbedaan litologi yaitu peralihan dari endapan vulkanik merapi ke formasi batuan tersier dari Pegungungan Baturagung dan Pegunungan Jiwo.

\section{Simpulan}

Vulkan Merapi selain memiliki potensi bahaya bagi masyarakat disisi lain juga menyimpan potensi sumberdaya alam yang sangat berharga bagi kehidupan, salah satunya sumberdaya air. Keberadaan mataair di bagian selatan Vulkan Merapi menunjukkan tingginya potensi sumberdaya air di wilayah ini. Faktor geomorfologi ternyata berpengaruh terhadap persebaran mataair. Selain bentuklahan, proses geomorfologi juga menentukan keberadaan mataair. Pola persebaran mataair di bagian selatan Vulkan Merapi yang membentuk sabuk mataair pada tekuk lereng menunjukkan pengaruh bentuklahan terhadap persebaran mataair. Sementara itu anomali berupa terbatasnya mataair pada tekuk lereng di sisi timur menunjukkan pengaruh proses geomorfologi terhadap pemunculan mataair. Informasi mengenai persebaran mataair sangat penting untuk mendukung pemanfaatan sumberdaya air secara optimal, khususnya untuk mendukung kegiatan pengelolaan kebencanaan. Perubahanperubahan bentuklahan dan proses geomorfologi yang terjadi relatif cepat akibat erupsi perlu menjadi perhatian dalam kaitannya dengan keberadaan mataair.

\section{Ucapan terima kasih}

Penulisan artikel dapat terselesaikan atas bantuan dari berbagai pihak. Oleh karenanya, penulis mengucapkan terima kasih kepada berbagai pihak yang telah membantu dalam pengumpulan data yakni BPBD Kabupaten Sleman, seluruh staf kantor desa serta seluruh masyarakat di Kecamatan Turi, Pakem, dan Cangkringan. Ucapan terima kasih secara khusus disampaikan kepada Kemenristekdikti yang telah membiayai penelitian ini melalui hibah Program Kreativitas Mahasiswa Penelitian Eksakta tahun 2017.

\section{Referensi}

Andreastuti, S. D., Newhall, C., \& Dwiyatno, J. (2006). Menelusuri kebenaran letusan Gunung Merapi 1006. Jurnal Geologi Indonesia, 1(4), 201-207. Retrieved from http://ijog.bgl.esdm.go.id

Ashari, A. (2014). Distribusi Spasial Mataair Kaitannya dengan Keberadaan Situs Arkeologi di Kaki Lereng Timur Gunungapi Sindoro antara Parakan dan Ngadirejo Kabupaten Temanggung. In D. R. S. Sumunar \& N. Khotimah (Eds.), Mega Seminar: Geografi Untukmu Negeri (pp. 169-179). Yogyakarta: Jurusan Pendidikan Geografi, Fakultas IImu Sosial, Universitas Negeri Yogyakarta.

Ashari, A. (2017). Geomorphology of the Southern Flank of Merapi Volcano in Relation to the Potential Hazards and Natural Resources: A Review. Geomedia, 15(2), 183-192.

Aurita, R. P., \& Purwantara, S. (2017). Karakteristik Mataair Kaki Lereng Gunung Merapi dan Pemanfaatannya di Kecamatan Dukun Kabupaten Magelang. Geomedia, 15(1), 75-85.

Badan Geologi. (2011). Peta Kawasan Rawan Bencana Gunung Merapi dan Area Terdampak Letusan 2010. Badan Geologi Kementerian Energi dan Sumberdaya Mineral. Retrieved from http://geospasial.bnpb.go.id/2011/05/04/pet a-kawasan-rawan-bencana-gunung-merapidan-area-terdampak-letusan-2010/

Badan Geologi. (2014). G. Merapi - Sejarah Letusan. Retrieved March 20, 2018, from http://www.vsi.esdm.go.id/index.php/gunung api/data-dasar-gunungapi/542-g- 
merapi $?$ start=1

BPS Kabupaten Sleman. (2017a). Kecamatan Cangkringan Dalam Angka 2017. Sleman: BPS Kabupaten Sleman.

BPS Kabupaten Sleman. (2017b). Kecamatan Pakem Dalam Angka 2017. Sleman: BPS Kabupaten Sleman.

BPS Kabupaten Sleman. (2017c). Kecamatan Turi Dalam Angka 2017. Sleman: BPS Kabupaten Sleman.

De Bélizal, E., Lavigne, F., Hadmoko, D. S. Degeai, J. P., Dipayana, G. A., Mutaqin, B. W., ... Aisyah, N. (2013). Rain-triggered lahars following the 2010 eruption of Merapi volcano, Indonesia: A major risk. Journal of Volcanology and Geothermal Research, 261, 330-347. https://doi.org/10.1016/j.jvolgeores.2013.01. 010

Degroot, V. (2009). Candi, Space and Landscape: A Study on the Distribution, Orientation and Spatial Organization of Central Javanese Temple Remains. Leiden: Leiden University. Retrieved from https://books.google.com/books?id=u2Hzdu ME8OcC\&pgis $=1$

Kurniati, E., Vikriyah, N., \& Ardana, N. (2016). Nice Tutorial SIG Lanjut: Sistem Informasi Geografis Tingkat Lanjut. Yogyakarta: Bilion Technology.

Nurhadi, Ashari, A., \& Suparmini. (2017). Karakteristik lingkungan fisik dan Infrastruktur kaitannya dengan tingkat kesiapsiagaan di Kawasan Rawan Bencana Erupsi Merapi. Geomedia, 15(2), 149-164.
Pramono, H., \& Ashari, A. (2014). Geomorfologi Dasar. (Hartono, Ed.). Yogyakarta: UNY Press.

Purnama, S. (2010). Hidrologi Air Tanah. Yogyakarta: Kanisius.

Raharjo, W., Sukandarrumidi, \& Rosidi, H. M. D. (1995). Peta Geologi Lembar Yogyakarta, Jawa. Bandung.

Santosa, L. W. (2006). Kajian hidrogeomorfologi mataair di sebagian lereng barat Gunungapi Lawu. Forum Geografi, 20(1), 68-85.

Simoen, S. (2001). Sistem Akuifer di Lereng Gunungapi Merapi Bagian Timur dan Tenggara, Studi Kasus di Kompleks Mataair Sungsang Boyolali Jawa Tengah, 15(1), 116.

Sutikno, Santosa, L. W., Widiyanto, Kurniawan, A., \& Purwanto, T. H. (2007). "Kerajaan Merapi", Sumberdaya Alam dan Daya Dukungnya. Yogyakarta: BPFG UGM.

Verstappen, H. T. (1983). Applied geomorphology: geomorphological surveys for environmental development. Amsterdam: Elsevier.

Verstappen, H. T. (2013). Garis Besar Geomorfologi Indonesia. (Suratman, Ed.) (1st ed.). Yogyakarta: Gadjah Mada University Press. 